\title{
ANALISIS HUBUNGAN FAKTOR MATERNAL DAN PENYAKIT KRONIK PADA PERSALINAN PREMATUR
}

\author{
Eni Mustika ${ }^{1}$, Fika Minata ${ }^{2}$ \\ Fakultas Kebidanan dan Keperawatan Universitas Kader Bangsa Palembang1 \\ Fakultas Kesehatan Masyarakat, Universitas Indonesia ${ }^{2}$ \\ J1.Mayjen. H. M. Ryacudu No.88, 7 Ulu Kecamatan seberang Ulu I ${ }^{1}$ \\ Jalan Margonda Raya, Pondok Cina, Kota Depok, Jawa Barat ${ }^{2}$ \\ Email : enimustikaharahap92@gmail.com, fika.minata@ui.ac.id
}

\begin{abstract}
Abstrak
Kematian Neonatal mencapai 15 per 1.000 kelahiran hidup, $45 \%$ disebabkan persalinan prematur. Persalinan prematur adalah persalinan yang terjadi pada usia kehamilan kurang dari 37 minggu dengan berat janin kurang dari 2500 gram. Prevalensi persalinan prematur di Indonesia meningkat di tahun 2014 15,5\% menjadi 29,5\% tahun 2019. Persalinan prematur di RSU YK Madira juga meningkat di tahun 2018 5,7\% menjadi 8\% tahun 2019. Tujuan penelitian adalah mengetahui hubungan faktor maternal dan penyakit kronik terhadap persalinan prematur seperti kenaikan BB selama kehamilan, diabetes, tekanan darah ibu, anemia dan riwayat infeksi. Metode yang digunakan adalah survey analitik dengan cross sectional. Populasi penelitian ini adalah seluruh ibu bersalin dan total sampel 202 responden. Hasil penelitian dari 202 responden yang mengalami persalinan prematur 72 responden (35,6\%) dan tidak prematur 130 responden (64,4\%). Hasil uji statistik didapatkan ada hubungan yang bermakna kenaikan BB selama kehamilan ( $p$-value $=0.001)$, tekanan darah ibu ( $p$-value $=0.001)$, anemia $(p$-value $=0.001)$, riwayat infeksi $(p$-value $=0.040)$ dan tidak ada hubungan bermakna antara diabetes $(p$-value $=0.211)$ dengan persalinan prematur. Kesimpulan yaitu variabel dominan terhadap persalinan prematur adalah anemia $(O R=21.741$, $p$-value $=0.000)$
\end{abstract}

Kata kunci : Faktor Maternal, Penyakit Kronik, Persalinan Prematur.

\begin{abstract}
Neonatal mortality reaches 15 per 1,000 live births, $45 \%$ due to preterm delivery. Preterm labor is delivery that occurs at less than 37 weeks of gestation and the fetus weighs less than 2500 grams. The prevalence of preterm labor in Indonesia increased by $15.5 \%$ in 2014 to $29.5 \%$ in 2019. Preterm labor at YK Madira General Hospital also increased in 2018 by 5.7\% to 8\% in 2019. The study aimed to determine the relationship between maternal factors and chronic disease on preterm labor such as increased weight gain during pregnancy, diabetes, maternal blood pressure, anemia, and history of infection. . The method used was a cross-sectional analytic survey. The population of this study was all mothers who gave birth and a total sample of 202 respondents. The results of the study of 202 respondents who experienced preterm labor were 72 respondents (35.6\%) and 130 respondents (64.4\%) who were not preterm. The results of statistical tests showed that there was a significant relationship between increased body weight during pregnancy ( -value $=0.001)$, maternal blood pressure ( $p$-value $=$ $0.001)$, anemia $(p$-value $=0.001)$, history of infection $(p$-value $=0.040)$ and there is no significant relationship between diabetes ( $p$-value $=0.211$ ) with preterm labor. The conclusion is that the dominant variable for preterm labor is anemia $(O R=21.741$, $p$-value $=0.000)$.
\end{abstract}

Keywords: Maternal Factors, Chronic Disease, Preterm Labor 


\section{PENDAHULUAN}

Angka Kematian Neonatal (AKN) mencapai 15 per 1.000 kelahiran hidup, AKB yaitu 24 per 1.000 kelahiran hidup dan Angka Kematian Balita (AKBA) yaitu 35 per 1.000 kelahiran hidup. Kematian neonatal empat puluh lima persen disebabkan oleh persalinan prematur sebesar 947.000 kelahiran jiwa (Indonesia, 2014). Persalinan prematur adalah persalinan yang terjadi pada usia kehamilan kurang dari 37 minggu dengan perkiraan berat janin kurang dari 2500 gram (Manuaba, 2012). Prematur merupakan penyebab kematian kedua pada balita setelah pneumonia dan merupakan penyebab utama kematian neonatal. Empat puluh lima persen kematian neonatal di dunia disebabkan oleh komplikasi persalinan prematur (Indonesia, 2014). Persalinan prematur terbagi menjadi, Usia kehamilan 32-36 minggu disebut persalinan prematur (preterm), usia kehamilan 28-32 minggu disebut persalinan sangat prematur (very preterm) dan usia kehamilan 20-27 minggu disebut persalinan ekstrim prematur (extremely preterm)

Kejadian persalinan prematur terbanyak di Dunia tahun 2010 yaitu India sebanyak 3.519.100 dan terendah di Brazil sebanyak 279.300 per 1.000 kelahiran hidup, sedangkan Indonesia merupakan negara kelima dengan jumlah persalinan prematur sebesar 675.700 per 1.000 kelahiran hidup. (WHO, 2015). Hal ini terjadi karena masih banyaknya ibu yang hamil di usia tua, gaya hidup ibu yang tidak sehat dan pertumbuhan janin yang terhambat (Djama, 2017).

Prevalensi persalinan prematur di Indonesia mengalami peningkatkan tahun 2014 yaitu 15,5\%, tahun 2015 menjadi 19\% dan menurun di tahun 2016 yaitu 14\%, meningkat lagi di tahun 2018 yaitu 13,8\% dan 2019 menjadi $29,5 \%$ per 1.000 kelahiran hidup (Rencana Strategis Kementrian Kesehatan Tahun 2015-2019, 2015).

Angka kematian neonatal di Sumatera Selatan mengalami penurunan setiap tahunnya, yaitu di tahun 2015 mencapai 578 kasus, tahun 2016 yaitu 556 kasus, tahun 2017 yaitu 540 kasus, tahun 2018 yaitu 445 kasus dan tahun 2019 menjadi 422 kasus. Akan tetapi angka tersebut masih tinggi dan masih perlu berbagai upaya untuk menurunkannya. Kematian neonatal empat puluh delapan persen disebabkan oleh persalinan prematur, tiga puluh enam persen asfiksia neonatorm, sebelas persen kelainan bawaan, tiga persen sepsis dan dua persen tetanus (Profil Dinkes Sumatera Selatan, 2020).

Angka Kematian Neonatal (AKN) di Kota Palembang mengalami penurunan, yaitu pada tahun 2013 sebanyak 68 kasus, 2014 ada 47 kasus, 2015 yaitu 12 kasus dan meningkat di tahun 2016 menjadi 20 kasus. Hal ini dipicu karena akses pelayanan yang sulit untuk penanganan neonatal dengan kasus BBLR (Dinkes Kota Palembang, 2018).

Prevalensi persalinan prematur di RSU YK Madira mengalami peningkatan setiap tahunnya yaitu tahun 2017 sebanyak 59 kasus 1.091 persalinan $(5,4 \%)$, tahun 2018 menjadi 57 kasus dari 987 persalinan $(5,7 \%)$ dan tahun 2019 mencapai 72 kasus dari 899 persalinan (8\%) (Instalasi Rekam Medis dan Casemix RSU YK Madira Palembang, 2019).

Dampak persalinan prematur yaitu pada ibu setelah persalinan prematur, infeksi endometrium lebih sering terjadi sehingga menyebabkan sepsis dan lambatnya penyembuhan luka episiotomi. Pada bayi prematur terutama yang lahir dengan usia kurang dari 32 minggu mempunyai resiko kematian 70 kali lebih tinggi dari bayi yang lahir normal. Karena mereka memiliki kesulitan untuk beradaptasi dengan dunia luar akibat ketidakmatangan sistem organ tubuhnya. Seperti paru-paru, jantung, ginjal, hati dan sistem pencernaan. Bayi prematur berisiko tinggi untuk menderita sepsis, hipotermi, dan hipoglikemi. Kondisi ini menyebabkan bayi prematur memiliki risiko tinggi untuk mengalami kematian. Hal ini dapat mengakibatkan rendahnya kualitas sumber daya manusia di masa yang akan datang (Rima, 2010).

Faktor - faktor persalinan prematur diantaranya, penyakit ibu seperti hipertensi, 
anemia, diabetes dan asma (Rukiah, 2014). Faktor pemicu persalinan prematur yaitu faktor ibu atau maternal seperti infeksi pada ibu, pertambahan berat badan ibu selama (Solama, 2019). Hasil penelitian di RSUD Dr. Pirngadi Kota Medan, ada hubungan antara hipertensi $(\mathrm{p}=0.002)$ anemia $(\mathrm{p}=0.005)$, status gizi $(\mathrm{p}=0.027)$ dengan kejadian persalinan prematur (Fransiska Simbolon, Sori Muda Sarumpaet, 2015). Hasil penelitian di RSUD Tugurejo Semarang, menunjukkan ada hubungan antara penambahan berat badan $(\mathrm{p}=0.001)$ dengan persalinan prematur (Niswah, 2016). Hasil penelitian di RSUD Gorontalo menunjukan bahwa riwayat infeksi $(\mathrm{OR}=5.6)$ memilki hubungan yang erat dengan persalinan prematur (Mira et al, 2014). Penelitian lain menunjukan bahwa ibu yang mengalami penyakit komplikasi (hipertensi, penyakit jantung yang berat dan diabetes) lebih beresiko mengalami persalinan prematur (Maita, 2012).

Berdasarkan uraian diatas maka peneliti tertarik untuk melakukan penelitian tentang "Analisis Hubungan Faktor Maternal dan Penyakit Kronik pada Persalinan Prematur di RSU YK Madira Palembang Tahun 2019".

\section{METODE PENELITIAN}

\section{Jenis Penelitian}

Jenis penelitian ini menggunakan metode Survey Analitik dengan pendekatan cross sectional yaitu penelitian yang mempelajari dinamika korelasi antara faktor-faktor resiko dengan efek. Dengan tujuan untuk mengetahui hubungan variabel indevenden (kenaikan BB ibu selama kehamilan, diabetes, tekanan darah ibu, anemia, riwayat infeksi) dengan variabel dependen (persalinan prematur) dengan cara pendekatan, observasi, atau pengumpulan data secara bersamaan pada saat itu (Point Time Approach) (Notoatmodjo, 2012).

\section{Waktu dan Tempat Penelitian}

Penelitan ini dilakukan pada tanggal 06 - 17 Juli 2020 di RSU YK Madira Palembang

\section{Target/Subjek Penelitian}

Populasi penelitian ini adalah semua data ibu bersalin yang tercatat di rekam medis RSU YK Madira Palembang pada tahun 2019 sebanyak 899 kasus.

Sampel dalam penelitian sebanyak 202 kasus yang ditentukan berdasarkan rumus estimasi proporsi Lemeshowb, 1997. Pengambilan sampel secara acak atau simple random sampling.

\section{Data, Intrumen, dan Teknik Pengumpulan Data}

Data sekunder, yaitu data atau sumber informasi yang bukan dari tangan pertama dan yang bukan mempunyai wewenang dan tanggung jawab terhadap informasi atau data tersebut (Notoatmodjo, 2012).

Pada penelitian ini data yang digunakan adalah data Sekunder, yaitu data penelitian yang didapatkan secara tidak langsung seperti dari buku catatan atau data laporan yang telah tersedia di rekam medis RSU YK Madira Palembang Tahun 2019

\section{Teknik Analisis Data}

Analisis univariat bertujuan untuk melihat distribusi frekuensi dan persentasi variabel independen (kenaikan BB selama kehamilan, diabetes, tekanan darah ibu, anemia, riwayat infeksi) dan variabel dependen (persalinan prematur).

Analisis bivariat ini bertujuan untuk mengetahui hubungan secara simultan (keseluruhan) dan parsial (secara satu per satu) antara variabel independen dengan variabel dependen. Pada analisis bivariat ini menggunakan uji Chi-Square test dengan tingkat kemaknaan $\alpha(0.05)$. Pengambilan keputusan statistic dilakukan dengan membandingkan nilai $\mathrm{p}$ (p-value) dengan nilai $\alpha(0.05)$ dengan ketentuan :

1. Jika $p$-value $<0.05$, maka ada hubungan antara variabel Independen dan variabel Dependen.

2. Jika $p$-value > 0.05 , maka tidak ada hubungan antara variabel Independen dan variabel Dependen. (Notoadmojdo, 2012) 
3. Analisis multivariat dilakukan untuk melihat variabel independen yang paling berpengaruh terhadap variabel dependen. Analisis multivariat yang digunakan adalah regresi logistik model prediksi,No. dengan tingkat kepercayaan $95 \%$ dan menggunakan metode menentukan odds rasio variabel kategorik polikontom dengan salah satu kategori menjadi pembanding dengan cara chi-square.

\section{HASIL PENELITIAN PEMBAHASAN}

1. Analisis Univariat

Tabel 1

Karakteristik Responden ( $\mathrm{N}=202)$

\begin{tabular}{ccc}
\hline Variabel & f & $\%$ \\
\hline Persalinan Prematur & & \\
Ya & 72 & 35,6 \\
Tidak & 130 & 64,4 \\
\hline $\begin{array}{c}\text { Kenaikan BB Selama } \\
\text { Kehamilan }\end{array}$ & 63 & 31,2 \\
Normal & 139 & 68,6 \\
Tidak Normal & & \\
Diabetes & & \\
Ya & 16 & 7,9 \\
Tidak & 186 & 92,1 \\
\hline Tekanan Darah Ibu & & \\
Normal & 143 & 70,8 \\
Tidak Normal & 59 & 29,2 \\
\hline Anemia & & \\
Ya & 132 & 65,3 \\
Tidak & 70 & 34,7 \\
\hline Riwayat Infeksi & & \\
Ada & 38 & 18,8 \\
Tidak Ada & 164 & 81,2 \\
\hline
\end{tabular}

Tabel 1 menunjukan bahwa dari 202 responden ada sebanyak 72 responden $(35,6 \%)$ yang mengalami persalinan prematur, 139 responden $(68,8 \%)$ yang kenaikan BB selama kehamilan tidak normal, 186 responden $(92,1 \%)$ yang tidak memiliki penyakit diabetes, 143 responden $(70,8 \%)$ yang mememiliki tekanan darah normal, 132 responden $(65,3 \%)$ yang mengalami anemia dan 164 responden $(81,2 \%)$ yang tidak memiliki riwayat infeksi.

\section{Analisis Bivariat}

Tabel 2
Distribusi Responden Berdasarkan Kenaikan

BB Ibu Selama Kehamilan di RSU YK Madira Tahun 2019

\begin{tabular}{|c|c|c|c|c|c|c|c|c|}
\hline \multirow{2}{*}{$\begin{array}{c}\text { Kenaik } \\
\text { an BB } \\
\text { Ibu } \\
\text { Selama } \\
\text { Keham } \\
\text { ilan } \\
\end{array}$} & \multicolumn{4}{|c|}{$\begin{array}{l}\text { Persalinan } \\
\text { Prematur }\end{array}$} & \multirow{2}{*}{\multicolumn{2}{|c|}{$\underset{\mathbf{h}}{\text { Jumla }}$}} & \multirow[t]{2}{*}{$\rho$} & \multirow[t]{2}{*}{ OR } \\
\hline & \multicolumn{2}{|c|}{ Iya } & \multicolumn{2}{|c|}{ Tidak } & & & & \\
\hline & $\mathrm{n}$ & $\%$ & $\mathrm{n}$ & $\%$ & $\mathrm{n}$ & $\%$ & & \\
\hline Normal & 12 & 19,0 & 51 & 81,0 & 63 & 100 & 0,0 & \\
\hline Tidak & 60 & 43,2 & 79 & 56,8 & 139 & 100 & 01 & 0,31 \\
\hline Normal & & & & & & & & 0 \\
\hline Total & 72 & & 130 & & 202 & 100 & & \\
\hline
\end{tabular}

63 responden yang kenaikan BB ibu selama kehamilan yang normal ada 12 responden $(19,0 \%)$ yang mengalami persalinan prematur, sedangkan dari 139 responden yang kenaikan BB ibu selama kehamilan tidak normal sebanyak 60 responden $(43,2 \%)$ yang mengalami persalinan prematur. Hasil uji statistik chi-square diperoleh nilai $\mathrm{p}=0.001$ (lebih kecil dari $\alpha$ 0.05) maka dapat disimpulkan bahwa ada hubungan yang bermakna antara kenaikan BB ibu selama kehamilan dengan persalinan prematur.

Hasil analisis diperoleh nilai $\mathrm{OR}=$ 0.310 , yang bearti responden yang termasuk dalam kenaikan BB selama kehamilan yang tidak normal mempunyai peluang 0.310 kali mengalami persalinan prematur dibandingkan yang normal. Hal ini sama dengan hasil penelitian di RSUD Tugurejo Semarang, bahwa ada hubungan yang signifikan antara kenaikan berat badan ibu hamil yang tidak sesuai ( $\mathrm{p}$-value $=0.001$, $\mathrm{OR}=22.066,95 \% \mathrm{CL}=4849-100406$ ) dengan kejadian persalinan prematur (Niswah, 2016).

Rendahnya penambahan berat badan ibu hamil dapat meningkatkan risiko persalinan prematur. Sebaliknya penambahan berat badan ibu yang berlebihan juga dapat berisiko mengalami perdarahan atau indikasi awal terjadinya keracunan kehamilan/preeklamsia yang dapat menyebabkan persalinan prematur (Wahyono, 2010). 
Tabel 3

Distribusi Responden Berdasarkan Diabetes di RSU YK Madira Tahun 2019

\begin{tabular}{|c|c|c|c|c|c|c|c|c|}
\hline \multirow{3}{*}{$\begin{array}{c}\text { Diabet } \\
\text { es }\end{array}$} & \multicolumn{4}{|c|}{ Persalinan Prematur } & \multicolumn{2}{|c|}{ Jumlah } & \multirow[t]{2}{*}{$\mathbf{P}$} & \multirow{2}{*}{$\begin{array}{l}\mathbf{O} \\
\mathbf{R} \\
\end{array}$} \\
\hline & \multicolumn{2}{|c|}{ Iya } & \multicolumn{2}{|c|}{ Tidak } & & & & \\
\hline & $\mathrm{n}$ & $\%$ & $\mathrm{n}$ & $\%$ & $\mathrm{n}$ & $\%$ & & \\
\hline Iya & 8 & 50,0 & 8 & 50,0 & 16 & 100 & 0 , & 1, \\
\hline Tidak & 64 & 34,4 & 122 & 65,6 & 86 & 100 & 21 & 90 \\
\hline Total & 72 & & 130 & & 02 & 100 & 1 & 6 \\
\hline
\end{tabular}

Berdasarkan tabel 3 diatas, bahwa dari 16 responden yang memiliki penyakit diabetes sebanyak 8 responden $(50,0 \%)$ yang mengalami persalinan, sedangkan dari 186 responden yang tidak memiliki penyakit diabetes sebanyak 64 responden $(34,4 \%)$ yang mengalami persalinan prematur. Hasil uji statistik chi-square diperoleh nilai $\mathrm{p}=$ 0.211 (lebih besar dari $\alpha 0.05$ ) maka dapat disimpulkan bahwa tidak ada hubungan yang bermakna antara diabetes dengan persalinan prematur.

Hasil analisis diperoleh nilai OR = 1.906, yang artinya responden yang memiliki penyakit diabetes mempunyai peluang 1.906 kali mengalami persalinan prematur dibandingkan yang tidak memiliki penyakit diabetes. Hal ini sejalan dengan hasil penelitian di RSUD Mojokerto bahwa tidak ada hubungan bermakna antara diabetes $(p$-value $=0.214)$ dengan persalinan prematur (Dwi et al., 2014), dan bertolak belakang dengan hasil penelitian di lima Rumah Sakit Kesehatan Ibu dan Anak di Beijing, yang menunjukan bahwa ada hubungan antara diabetes dengan persalinan prematur $(\mathrm{OR}=3.441,95 \%$ CI1.694-6.991) (Zhang et al., 2012).

Diabetes Mellitus adalah penyakit gangguan metabolik yang di tandai oleh kenaikan gula darah akibat penurunan sekresi insulin oleh sel beta pankreas dan atau ganguan fungsi insulin (resistensi insulin) (Fatimah, 2016). Kondisi tersebut dapat menyebabkan kerusakan di berbagai jaringan dalam tubuh mulai dari pembuluh darah, mata, ginjal, jantung dan syaraf. Serta dapat memicu komplikasi persalinan jika terjadi pada ibu hamil dan mengakibatkan persalinan prematur yang disebut dengan komplikasi dari diabetes melitus (Kurniasari \& Arifandini, 2015).

Tabel 4

Distribusi Responden Berdasarkan Hipertensi dan Tekanan Darah Ibu di RSU YK Madira Tahun 2019

\begin{tabular}{|c|c|c|c|c|c|c|c|c|}
\hline \multirow{3}{*}{$\begin{array}{c}\text { Tekanan } \\
\text { Darah } \\
\text { Ibu }\end{array}$} & \multicolumn{4}{|c|}{ Persalinan Prematur } & \multirow{2}{*}{\multicolumn{2}{|c|}{ Jumlah }} & \multirow[t]{2}{*}{$\boldsymbol{\rho}$} & \multirow{2}{*}{$\begin{array}{l}\mathbf{O} \\
\mathbf{R}\end{array}$} \\
\hline & \multicolumn{2}{|c|}{ Iya } & \multicolumn{2}{|c|}{ Tidak } & & & & \\
\hline & $\mathrm{n}$ & $\%$ & $\mathrm{n}$ & $\%$ & $\mathrm{n}$ & $\%$ & \multirow[b]{2}{*}{0} & \multirow[b]{2}{*}{0 , } \\
\hline \multirow{3}{*}{$\begin{array}{c}\text { Normal } \\
\text { Tidak } \\
\text { Normal }\end{array}$} & 23 & 16,1 & 120 & 83,9 & 143 & 100 & & \\
\hline & 49 & 83,1 & 10 & 16,9 & 59 & 100 & 00 & 03 \\
\hline & & & & & & & 1 & 9 \\
\hline Tota & & 72 & & 130 & & 202 & & 0 \\
\hline
\end{tabular}

Berdasarkan tabel 4 diatas, bahwa dari 143 responden yang tekanan darah ibu normal sebanyak 23 responden $(16,1 \%)$ yang mengalami persalinan prematur, sedangkan dari 59 responden yang tekanan darah ibu tidak normal sebanyak 49 responden $(83,1 \%)$ yang mengalami persalinan prematur. Hasil uji statistik chisquare diperoleh nilai $\mathrm{p}=0.001$ (lebih kecil dari $\alpha$ 0.05) maka dapat disimpulkan bahwa ada hubungan yang bermakna antara tekanan darah ibu dengan persalinan prematur.

Hasil analisis diperoleh nilai $\mathrm{OR}=$ 0.039 , yang artinya responden yang termasuk dalam tekanan darah ibu yang tidak normal mempunyai peluang $0.039 \mathrm{kali}$ mengalami persalinan prematur dibandingkan tekanan dara ibu normal. Hal ini sejalan dengan hasil penelitian di RSUD DR. Soedarso Pontianak bahwa ada hubungan bermakna antara hipertensi dengan kejadian persalinan prematur. Hasil uji statistik $\mathrm{p}=0.002$ dan $\mathrm{OR}=3.116$ (Amaliah et al., 2014).

Tekanan darah adalah tekanan yang terjadi pada dinding arteri. Tekanan puncak terjadi saat ventrikel berkontraksi, yang disebut tekanan sistolik. Sedangkan tekanan terendah yang terjadi saat jantung beristirahat disebut tekanan diastolik. Ratarata tekanan darah normal $120 / 80 \mathrm{mmHg}$ (Endang, 2014). Tekanan darah dapat 
menyebabkan seorang wanita hamil mengalami persalinan prematur Karena tekanan darah yang tinggi akan menyebabkan penyempitan pada pembuluh darah dan mengakibatkan tonus otot rahim berkontraksi yang akan memicu persalinaNo. prematur. (Triyanto, 2014).

\section{Tabel 5}

\begin{tabular}{|c|c|c|c|c|c|c|c|c|c|}
\hline \multirow{3}{*}{ nako. } & \multirow{3}{*}{$\begin{array}{l}\text { Riwayat } \\
\text { Infeksi }\end{array}$} & \multicolumn{4}{|c|}{ Persalinan Prematur } & \multirow{2}{*}{\multicolumn{2}{|c|}{ Jumlah }} & \multirow[t]{2}{*}{$\rho$} & \multirow[t]{2}{*}{ OR } \\
\hline & & \multicolumn{2}{|c|}{ Iya } & \multicolumn{2}{|c|}{ Tidak } & & & & \\
\hline & & $\mathrm{n}$ & $\%$ & $\mathrm{n}$ & $\%$ & $\mathrm{n}$ & $\%$ & \multirow{4}{*}{$\begin{array}{l}0, \\
04 \\
0\end{array}$} & \multirow{4}{*}{$\begin{array}{l}2,09 \\
4\end{array}$} \\
\hline 1. & Ada & 19 & 50,0 & 19 & 50,0 & 38 & 100 & & \\
\hline 2. & Tidak Ada & 53 & 32,3 & 111 & 67,7 & 164 & 100 & & \\
\hline nia & Total & 72 & & 130 & & 20 & 100 & & \\
\hline
\end{tabular}

Distribusi Responden Berdasarkan Anemia di RSU YK Madira Tahun 2019

Tabel 5.11

Distribusi Responden Berdasarkan Riwayat Infeksi di RSU YK Madira Tahun 2019

\begin{tabular}{cccccccccc}
\hline \multirow{2}{*}{$\begin{array}{c}\text { Anem } \\
\text { ia }\end{array}$} & \multicolumn{4}{c}{ Persalinan Prematur } & \multirow{2}{*}{ Jumlah } & P & OR \\
\cline { 2 - 7 } & \multicolumn{2}{c}{ Iya } & \multicolumn{3}{c}{ Tidak } & & & & \\
\cline { 2 - 7 } & $\mathrm{n}$ & $\%$ & $\mathrm{n}$ & $\%$ & $\mathrm{n}$ & $\%$ & & \\
\hline Iya & 69 & 52,3 & 63 & 47,7 & 132 & 100 & 0, & 45,9 \\
Tidak & 3 & 4,3 & 67 & 95,7 & 70 & 100 & 00 & 1 \\
\hline Total & 72 & & 130 & & 202 & 100 & 1 & \\
\hline
\end{tabular}

Berdasarkan tabel 5 diatas, bahwa dari 132 responden anemia sebanyak 69 responden (52,3\%) yang mengalami persalinan prematur, sedangkan dari 70 responden tidak anemia sebanyak 3 responden $(4,3 \%)$ yang mengalami persalinan prematur. Hasil uji statistik chisquare diperoleh nilai $\mathrm{p}=0.001$ (lebih kecil dari $\alpha 0.05)$ maka dapat disimpulkan bahwa ada hubungan yang bermakna antara anemia dengan persalinan prematur.

Hasil analisis diperoleh nilai OR = 45.91, yang artinya responden yang mengalami anemia mempunyai peluang 45.91 kali mengalami persalinan prematur dibandingkan yang tidak anemia. Hal ini sama seperti hasil penelitian di RSUD Ogan Ilir, bahwa ada hubungan yang bermakna antara anemia dengan kejadian persalinan prematur, dengan hasil uji statistik $\mathrm{p}=0.002$ dan OR=14.037 (Dewi., 2019)

Anemia adalah terjadi pengurangan jumlah sel darah merah sehingga tidak mampu memenuhi fungsinya sebagai pembawa oksigen keseluruh jaringan tubuh manusia (Johnson Wimbley \& Graham, 2011). Pada saat ibu hamil mengalami kekurangan zat besi akan timbul keluhan merasa lelah meskipun tidak beraktivitas, kulit pucat, denyut jantung cepat, sulit bernafas dan sulit konsentrasi. Batas kadar hemoglobin (WHO, 2014)
Berdasarkan tabel 6 diatas, bahwa dari 38 responden yang memiliki riwayat infeksi sebanyak 19 responden $(50,0 \%)$ yang mengalami persalinan prematur, sedangkan dari 164 responden yang tidak memiliki riwayat infeksi sebanyak 53 responden $(32,3 \%)$ yang mengalami persalinan prematur. Hasil uji statistik chi square diperoleh nilai $\mathrm{p}=0.040$ (lebih kecil dari $\alpha$ 0.05) maka dapat disimpulkan bahwa ada hubungan yang bermakna antara riwayat infeksi dengan persalinan prematur.

Hasil analisis diperoleh nilai OR = 2.094, artinya : responden yang memiliki riwayat infeksi berisiko 2.094 kali mengalami persalinan prematur dibandingkan yang tidak ada riwayat infeksi. Hal ini sama seperti hasil penelitian di RSUD dr. Soetomo Surabaya menunjukan bahwa Prevalensi persalinan prematur $18,84 \%$ dari seluruh persalinan dengan faktor infeksi sebesar $68,7 \%$. Hal ini menunjukan bahwa ibu yang mempunyai riwayat infeksi lebih beresiko mengalami persalinan prematur (Hidayati, 2016).

Infeksi adalah penyakit yang disebabkan oleh masuknya mikroorganisme yaitu bakteri, virus, jamur dan protozoa kedalam tubuh sehingga menyebabkan kerusakan organ (Rahwan Ahmad, 2017).

\section{Analisis Multivariat}

\section{Tabel 7}

Hasil Analisis Multivariat Regresi Logistik

Model Ketiga Antara 3 Variabel Independen dengan Persalinan Prematur

\section{Model ketiga}

$\begin{array}{lllll}\text { Variabel } & \text { B } & \text { P-Value } & \text { OR } & \text { 95\% CI }\end{array}$




\begin{tabular}{|c|c|c|c|c|}
\hline $\begin{array}{l}\text { Kenaikan BB } \\
\text { Ibu Selama } \\
\text { Hamil }\end{array}$ & $\begin{array}{c}- \\
1,418\end{array}$ & 0,005 & 0,242 & $\begin{array}{c}0,089- \\
0,659\end{array}$ \\
\hline $\begin{array}{c}\text { Tekanan } \\
\text { Darah Ibu }\end{array}$ & $\begin{array}{c}- \\
3,284 \\
\end{array}$ & 0,000 & 0,037 & $\begin{array}{c}0,013- \\
0,104\end{array}$ \\
\hline Anemia & 3,079 & 0,000 & 21,741 & $\begin{array}{l}5,489- \\
86,116\end{array}$ \\
\hline Constant & 3,619 & 0,008 & 37,312 & \\
\hline
\end{tabular}

Dari hasil analisis regresi logistik pada 3 model atau model akhir (fit model) didapat 3 variabel yang bermakna secara statistik hubungannya dengan kejadian persalinan prematur. ketiga variabel tersebut adalah variabel kenaikan BB selama hamil, tekanan darah ibu dan anemia. Kemudian untuk mengetahui variabel yang paling besar pengaruhnya terhadap kejadian persalinan prematur dapat dilihat pada nilai Exp(B)/OR. Dari model 3 yang paling besar pengaruhnya terhadap kejadian persalinan prematur adalah variabel anemia dengan $\mathrm{OR}=21.741$ dan $\mathrm{p}$-value $=0.000$

\section{KESIMPULAN}

1. Ada hubungan bermakna antara kenaikan BB selama kehamilan dengan persalinan prematur di RSU YK Madira Tahun 2019 dengan $\mathrm{p}$-value $=0.001$.

2. Ada hubungan bermakna antara hipertensi dan tekanan darah ibu dengan persalinan prematur di RSU YK Madira Tahun 2019 dengan p-value $=0.001$.

3. Ada hubungan bermakna antara anemia dengan persalinan prematur di RSU YK Madira Tahun 2019 dengan $\mathrm{p}$-value = 0.001 .

4. Ada hubungan bermakna antara riwayat infeksi dengan persalinan prematur di RSU YK Madira Tahun 2019 dengan pvalue $=0.040$.

5. Tidak ada hubungan bermakna antara diabetes dengan persalinan prematur di RSU YK Madira Tahun 2019 dengan pvalue $=0.211$.

6. Variabel independen yang berhubungan dengan persalinan prematur yang dominan adalah variabel anemia dengan $\mathrm{OR}=21.741$ dan $\mathrm{p}$-value $=0.000$

\section{SARAN}

\section{Bagi RSU YK Madira Palembang}

Dapat meningkatkan kunjungan ibu hamil sesuai program pemerintah di RSU YK Madira Palembang melalui penyuluhan dan konseling oleh tenaga kesehatan agar kelainan ataupun komplikasi dalam kehamilan dapat terdeteksi lebih awal. Semoga penelitian ini dapat menjadi tolak ukur dalam meningkatkan kualitas pelayanan kebidanan.

\section{Bagi Universitas Kader Bangsa}

Diharapkan hasil penelitian ini dapat menjadi bahan kepustakaan/ referensi dalam perkuliahan di Universitas Kader Bangsa.

\section{Bagi peneliti selanjutnya}

Diharapkan agar peneliti selanjutnya dapat memperluas variabel yang berhubungan dengan persalinan prematur dari suatu teori yang dapat dipahami dan sesuai dengan kemampuan peneliti.

\section{UCAPAN TERIMA KASIH}

Penulis mengucapkan terima kasih kepada dosen pembimbing dan teman teman yang telah membantu dalam penelitian ini dan terkhusus kepada kedua orang tua, suami dan saudara-saudara saya yang telah memberi dukungan financial terhadap penelitian ini.

\section{DAFTAR PUSTAKA}

Amaliah., Marlenywati., \& Muhammad Taufik. 2014. Faktor-Faktor Yang Berhubungan Dengan Kejadian Persalinan Prematur Di RSUD DR.Soedarso Pontianak. Openjurnal.unmuhpnk.ac.id. 1(1)

Atika., Fadhilah, D.N. 2017. PerbedaanKadar Interleukin 8 Dan Prostagladin E2 Antara Persalinan Preterm Dengan Kehamilan Preterm. Universitas Andalas. http://scholar.unand.ac.id/id/eprint/ 29752 
A'bidah Baana Syarif., 2016. Hubungan Usia Dengan Kejadian Persalinan Preterm Di RSUD Wonosari. Poltekkes Kemenkes Yogyakarta. http:/ejournal.poltekkesjogja.ac.id/i ndex.php

Badan Pusat Statistik (BPS). 2019. Sumatera Selatan Bayi Berat Badan Lahir Rendah (BBLR). Palembang: Badan Pusat Statistik Provinsi Sumatera Selatan. http://sumsel.bps.go.id

Dewi, B. P. (2019). Analisis Hubungan Faktor Epidemiologi dan Faktor yang Terjadi Selama Kehamilan dengan Kejadian Kelahiran Preterm di RSUD Ogan Ilir Tahun 2018. Jurnal Kesehatan Dan Pembangunan.

BKKBN. 2019. Keluarga Berencana Dan Kesehatan Reproduksi. Jakarta: BKKBN.

Bobak, L.2014, Keperawatan Maternity. Edisi 4. Jakarta : EGC.

Cunningham, FG. et al. 2014. Preterm Birth. In: William Obstetrics (22nd edition). New York.

Delti Anggina. 2018. Determinan Kejadian Persalinan Bayi Prematur Di RS Umum Pusat DR. Mohammad Hoesin Palembang. http://repository.unsri.ac.id/11005

Devi, K., Fiki, A. 2014. Hubungan Usia, Paritas Dan Dabetes Mellitus Pada Kehamilan Dengan Kejadian Preeklamsia Pada Ibu Hamil Di Wilayah Kerja Puskesmas Rumbia Kabupaten Lampung Tengah.Jurnal Kesehatan Holistik. Vol 9 (3).

Dinas Kesehatan Kota Palembang. 2018. Profil Kesehatan Kota Palembang
Dinas Kesehatan Provinsi Sumatera Selatan. 2017. Profil Kesehatan Sumatera Selatan

Dwi, S., Sarni,M.B. 2013. Faktor-Faktor Yang Memengaruhi Kelahiran Prematur Di Indonesia: Analisis Data Riskesdas 2013. E-Journal Widya Kesehatan Dan Lingkungan. 1(2). Hal:109-115

Fina, I.N. 2016. Faktor Risiko Kejadian Persalinan Prematur (Studi Kasus di RSUD Tugurejo Semarang. Universitas Negeri Semarang. http:/lib.unnes.ac.id

Fransiska,R.S. 2013. Faktor Risiko Kejadian Persalinan Prematur di RSUD Dr. Pirngandi Kota Medan. Universitas Sumatera Utara. http://imoph2016.ui.ac.id>files

Kementrian Kesehatan RI. 2016. Profil Kementrian Kesehatan Republik Indonesia Tahun 2016. Jakarta: Pusat Data dan Informasi Kementrian Kesehatan Republik Indonesia.

Krisnadi, SR. 2015. Faktor Risiko Persalinan Prematur. Bandung: Refika Aditama.

Manuaba, IBG., (2015) Kapita Selekta Penatalaksanaan Rutin Obstetri Ginekologi Dan Kb. Jakarta: EGC.

Mira, A.K., Buraerah, H.A.H., \& A. Arsunan,A. 2016. Determinan Preterm Birth Event In Prof, DR.H.Aloei Saboe General Hospital Gorontalo City. Poltekkes Gorontalo. http://unha.ac.id.jurnal.file

M.Soleh Kosim. 2016. Gawat Darurat Neonatus Pada Preterm. Saripediatri.org. Sari Pediatri 7 (4), 225-31. 
Norwitz, E., Schorge, J., 2015. At A Glance Obstetri dan Ginekologi. Jakarta : Erlangga.

Noza Loviana. 2018. Hubungan Ketuban Pecah Dini, Anemia Dan Riwayat Persalinan Preterm Dengan Kejadian Persalinan Preterm Di RSUD Dr. Soetomo Surabaya. http://repository.unair.ac.d/86144/

Prawirohardjo, S. 2010. Ilmu Kebidanan. PT Bina Pustaka Sarwono Prawirohardjo.Jakarta. Hal: 667675.

Rima, Novalia. 2010. Persalinan Preterm.

Samarinda : Universitas

Mulawarman. http://

97539577/Persalinan-Preterm.

Riset Kesehatan Dasar (Rikesdas). 2018. Penelitian Dan Pengembangan Kesehatan. Jakarta : Dapartemen Kesehatan.

Rukiyah, Ai Yeyeh. 2015. Asuhan Kebidanan 4. Jakarta : CV. Trans Info Media.

Rukiyah, A.Y dan Lia Yulianti. 2010. Asuhan Patologi Kebidanan. Jakarta: Trans Info Medika.

SDKI. 2017. Survey demografi dan kesehatan Indonesia. Jakarta

Supariasa, I.D.N. dkk. 2013. Penilaian Status Gizi (Edisi Revisi). Jakarta: Penerbit Buku Kedokteran EGC.

Tambayong Jan. 2010. Patofisiologi Untuk Keperawatan. Jakarta: EGC.

Tatiyanantaporn, S. 2011. Maternal Risk Factor for Preterm Delivery. Kon Kaen Medical Journal.

Triyanto, Endang. 2014. Pelayanan Keperawatan Bagi Penderita
Hipertensi Secara Terpadu. Yogyakarta: Graha Ilmu.

UCSF. 2014. Preterm Birth is Now Leading Cause of Death in Young Children Globally. University of California, San Fransisco.

WHO. 2014. Born Too Soon : The Global Action Report on Preterm Birth.

Yolinda, C. A. 2012. Hubungan Faktor Maternal Dengan Kejadian Persalinan Prematur Di RSUD Tugurejo.UniversitasMuhammadiyah Semarang. http://repostory.unimus.ac.id/id/eprin $\mathrm{t} / 151$ 